\author{
Tomasz Śliwa*, Michał Kruszewski**, \\ Mohsen Assadi****, Aneta Sapińska-Śliwa*
}

\title{
THE APPLICATION OF VACUUM INSULATED TUBING IN DEEP BOREHOLE HEAT EXCHANGERS***
}

\section{INTRODUCTION}

Borehole Heat Exchanger (BHE) is being increasingly utilised for managing heat distribution in public as well as industrial housing [1]. Underground Thermal Energy Storage (UTES) is the subject of many new studies around the world [2-6]. Heat extraction can be often more easily obtained from boreholes than from regular geothermal water wells [7].

Main parameter affecting efficiency of BHE systems is characteristic of underground rock mass, which includes lithology of the rock formation and its hydrodynamic conditions. Following rock mass parameters cannot be regulated or changed during drilling process or heat production: geothermal gradient, natural heat flux of earth, thermal conductivity, diffusivity and density of rock mass, anisotropy of thermal conductivity of underground rock mass, specific heat of underground rocks, porosity, saturation and hydrodynamic characteristics of rock mass layers, type of reservoir fluids inside pores, natural velocity and direction of reservoir fluids filtration [8].

The heat flux reaching the earth's surface due to heat carrier circulation in BHE depends largely on heat exchanger's construction. This includes equipment installed for its primary purpose (e.g. casing strings) and equipment needed for adapting the well into BHE and extracting heat (e.g. inner column or cement plug). BHE's can be applied

* AGH University of Science and Technology, Faculty of Drilling, Oil and Gas, Krakow, Poland

** University of Stavanger, Faculty of Science and Technology

*** The paper was created within statute studies at the Faculty of Drilling, Oil and Gas at AGH University of Science and Technology in Krakow, Poland. Grant No. 11.11.190.555 
in vertical as well as in directional (oblique) wells (Geothermal Radial Drilling) [9]. Typical construction designs of BHE include: single U-pipe, multi U-pipe, coaxial (mostly DBHE) [6], helical BHE [10, 11], BHE in piles [12] and BHE with direct heat carrier evaporation (heat pump evaporator in underground rock mass) [13].

BHE can also be reconstructed from abandoned wells, which were originally utilised for other purposes, for instance oil or gas production wells. Existing boreholes can be further converted into DBHE's [14]. Some important construction and design characteristic required for typical well reconstruction includes: depth of packer or cement plug in negative or abandoned well, diameter of well, internal and external diameter and length of coaxial inner column, number, length and diameter of casing strings, quality and condition of material used for inner column insulation, heat resistance of material of the coaxial inner column, well inclination, centricity of internal coaxial column, distance between greater amount of BHE's [8].

Geological and construction design parameters described above influence greatly heat production from BHE systems and as a result of that its profitability. Operating parameters include the following mean annual heat production, heating power (maximum instantaneous and long-term), type of heat carrier, temperature of heat carrier, flow rate of heat carrier, flow resistance of heat carrier, rock mass temperature restoration (i.e. energy resource renewal), time of usage, distance between heat recipient and BHE, heat consumer type, heat rate, operating time and heat consumption, local climate [8]. Additionally, economic benefits depend highly on costs of different heat sources and its accessibility.

BHE's technology allows heat exchange between rock mass and heat carrier, circulating in closed-loop system between surface and underground reservoir. Borehole Thermal Energy Storage (BTES) is an underground system consisting of group of BHE's. These systems can supply heat in direct manner (passive - especially in deep wells) or with heat pumps (active), when harvesting low-enthalpy heat resources.

DBHE's can work only as a heat source. Such systems are expensive and involve finding a consumer in short distance from the borehole, as heat losses are significant [14]. During reconstruction of abandoned or negative wells for BHE's, inner column is the most important feature, which influences greatly technical, as well as economic success. The application of insulated inner pipe with lowest possible thermal conductivity can reduce drastically heat losses of heat carrier throughout the DBHE's length. As a result of that, insulated pipe will help to increase the temperature of heat uptake [15]. Well reconstruction for DBHE includes partial abandonment, which means removing heavy mud from the borehole, creating cement plug, sealing off perforated intervals and finally installing inner insulated column in leaktight, closed-loop system. Drilling a borehole especially for DBHE purposes is proven to be not profitable by previous researches [16]. 
Multi-layered insulated pipe that allowed steam injection to oil reservoirs was first introduced in 1970 by General Electric. This new technology enabled to increase efficiency of steam injections and lower operational costs. Further development allowed to increase insulation by introducing gas (e.g. argon) into annular of tubulars. In 1983 Babcock \& Wilcox launched double-layered Vacuum Insulated Tubing (VIT) that revolutionised the market by low heat transfer coefficient. In the mid 1980's interests in insulated pipes, as well as in Enhanced Oil Recovery (EOR) methods decreased, due to very low oil prices. Nowadays, Vacuum Insulated Tubing is widely applied in offshore technologies, permafrost regions (e.g. Alaska), Enhanced Recovery methods, Steam Assisted Gravity Drainage (SAGD), Annular Pressure Build-up (APB) mitigation, gas transition and in recent years in geothermal industry [17-20].

Figure 1 illustrates temperature profiles of DBHE with depth of $3000 \mathrm{~m}$. Circulation of closed-loop system in DBHE is executed by pumping heat carrier into the annular and carried through inner column to the surface. There are four different variants of insulating grades of different inner column construction presented on the graph. The lowest value of $0.01 \mathrm{~W} /(\mathrm{m} \cdot \mathrm{K})$ represents thermal conductivity of VIT, $0.12 \mathrm{~W} /(\mathrm{m} \cdot \mathrm{K})$ indicates good insulation, $1.16 \mathrm{~W} /(\mathrm{m} \cdot \mathrm{K})$ shows average insulation grade and $46.1 \mathrm{~W} /(\mathrm{m} \cdot \mathrm{K})$ represents no insulation (steel column) [21].

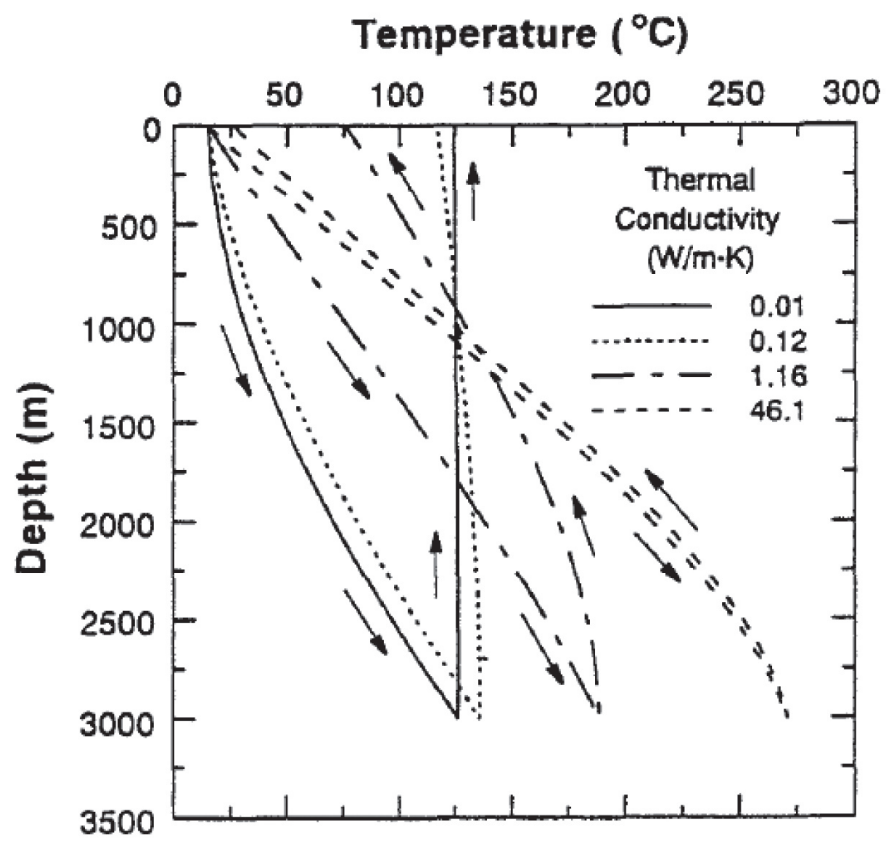

Fig. 1. Temperature profiles in coaxial DBHE of $3000 \mathrm{~m}$ depth for different values of thermal conductivity coefficients of inner column [21] 


\section{DIFFERENT CONSTRUCTION DESIGNS OF INNER COLUMN IN BHE}

Different BHE's construction designs are presented in Figure 2. The most common types of shallow BHE's are $2 \mathrm{c}$ and $2 \mathrm{~d}$ with single U-pipe and multiplied (double) U-pipe (e.g. in bearings pales of building constructions). U-pipes are applied in boreholes drilled especially for extracting heat from underground reservoirs, most often in depths equal or below $200 \mathrm{~m}$. Variant $2 \mathrm{~b}$ represents demi-type design encountered mostly in scientific literature concerning BHE's and heat pumps [22]. Unfortunately such construction of BHE's has no practical use. In DBHE or/and in BHE's adapted from existing wells, the most popular construction design is $2 \mathrm{a}$ with coaxial inner column.

Brief description of implementing coaxial inner column inside the well is presented below. The analysis of advantages and disadvantages of particular solutions was also investigated.

a)
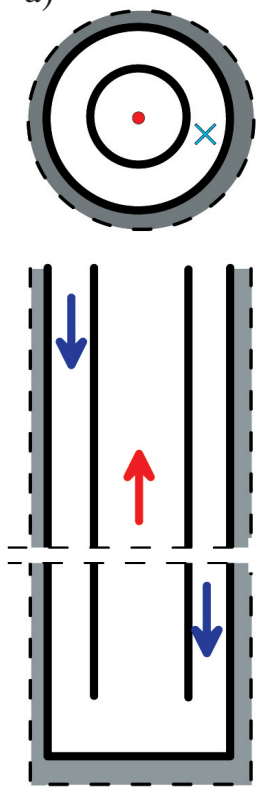

b)
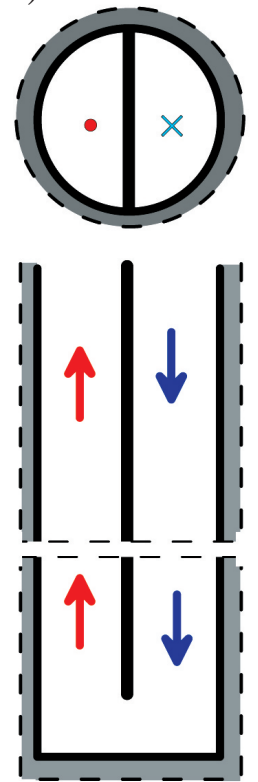

c)
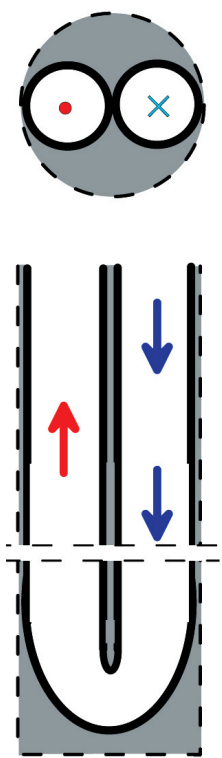

d)
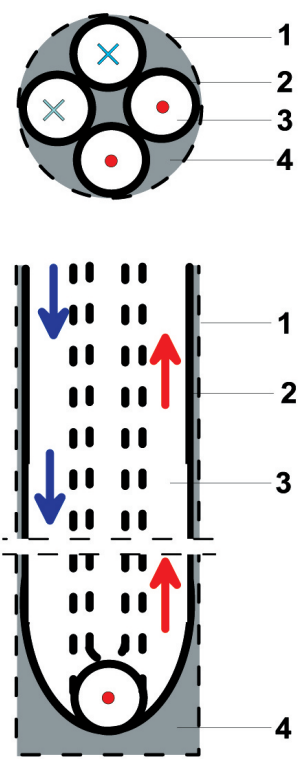

Fig. 2. Different construction designs of BHE: a) coaxial heat exchanger, b) demi-type heat exchanger, c) heat exchanger with single U-pipe, d) heat exchanger with double U-pipe [23]; 1 - wall of the borehole, 2 - heat exchanger pipe, 3 - heat carrier, 4 - sealant

\subsection{Single steel coaxial inner column}

One of the main advantages of this solution is well proven technique of creating inner column from steel pipes. Some of the other assets are availability of standard pipe 
diameters and lengths, variety of methods and types of centralisers that can be utilised and finally low prices of steel pipes (used drill pipes, casing strings and coiled-tubing can be also utilised) (Fig. 2a).

On the other hand, drilling rig with elevators and high hoisting capacity needs to be used to insert inner column at a proper depth. For lowering the weight of column and creating buoyancy effect, borehole needs to be filled with water or drilling mud. Other disadvantage is lack of heat insulation, this phenomenon is excluding use of conventional steel pipes in DBHE, what was confirmed by many studies around Europe [24, 25].

More effective outcome can be achieved by implementing fibre glass inner column. Such pipes are light in weight and can demonstrate much higher heat resistance than conventional steel ones. Unfortunately, costs of fibre glass pipes are higher. As for an example, Table 1 represents chosen characteristics of drill pipes with 2 7/8" (73 mm) diameter made from steel and fibre glass. Value of heat permeability coefficient, $\lambda$ of inner column's wall was determined by dividing thermal conductivity coefficient of inner column's material, $k$ and its wall thickness, $b$ :

$$
\lambda=\frac{k}{b}
$$

where:

$k$ - thermal conductivity coefficient of column's wall, $\mathrm{W} /(\mathrm{m} \cdot \mathrm{K})$,

$\lambda$ - heat permeability coefficient of column's wall, $\mathrm{W} /\left(\mathrm{m}^{2} \cdot \mathrm{K}\right)$,

$b$ - column wall thickness, $\mathrm{m}$.

Table 1

Example of $27 / 8$ inch $(73 \mathrm{~mm})$ drill pipes characteristic made from steel and fibre glass [26]

\begin{tabular}{|c|c|c|c|c|c|c|c|}
\hline \multirow{2}{*}{$\begin{array}{c}\text { Pipe } \\
\text { material }\end{array}$} & $\begin{array}{c}\text { Material } \\
\text { density, } \\
\rho\end{array}$ & $\begin{array}{c}\text { Unit } \\
\text { weight, } q\end{array}$ & $\begin{array}{c}\text { Outer } \\
\text { diameter, } \\
d_{\text {in }}\end{array}$ & $\begin{array}{c}\text { Inner } \\
\text { diameter, } \\
d_{\text {out }}\end{array}$ & $\begin{array}{c}\text { Wall } \\
\text { thickness, } \\
b\end{array}$ & $\begin{array}{c}\text { Thermal } \\
\text { conductivity } \\
\text { coefficient, } k\end{array}$ & $\begin{array}{c}\text { Heat } \\
\text { perme- } \\
\text { ability, } \lambda\end{array}$ \\
\cline { 2 - 8 } & $\mathrm{kg} / \mathrm{m}^{3}$ & $\mathrm{~N} / \mathrm{m}$ & $\mathrm{m}$ & $\mathrm{m}$ & $\mathrm{mm}$ & $\mathrm{W} /(\mathrm{m} \cdot \mathrm{K})$ & $\mathrm{W} /\left(\mathrm{m}^{2} \cdot \mathrm{K}\right)$ \\
\hline Steel C-75 & 7500 & 64.72 & 0.0730 & 0.0620 & 5.51 & 50.00 & 9074 \\
\hline Fibre glass & 1960 & 24.53 & 0.0716 & 0.0602 & 5.80 & 0.361 & 62 \\
\hline
\end{tabular}

\subsection{Double steel coaxial inner column with insulation fluid}

Such solution involves implementing double steel tubing with properly selected outer and inner diameters (Fig. 3), that will allow creating annular space between inner columns and casing strings for a gas or fluid heat carrier to circulate in the closed-loop 
system. At the bottomhole, inside inner column, packer (or plug) needs to be applied to seal the lower parts of the well and disable for heat carrier to filter into permeable rock mass below. In some cases, high gas pressure needs to be maintained to eliminate permeating of heat carrier.

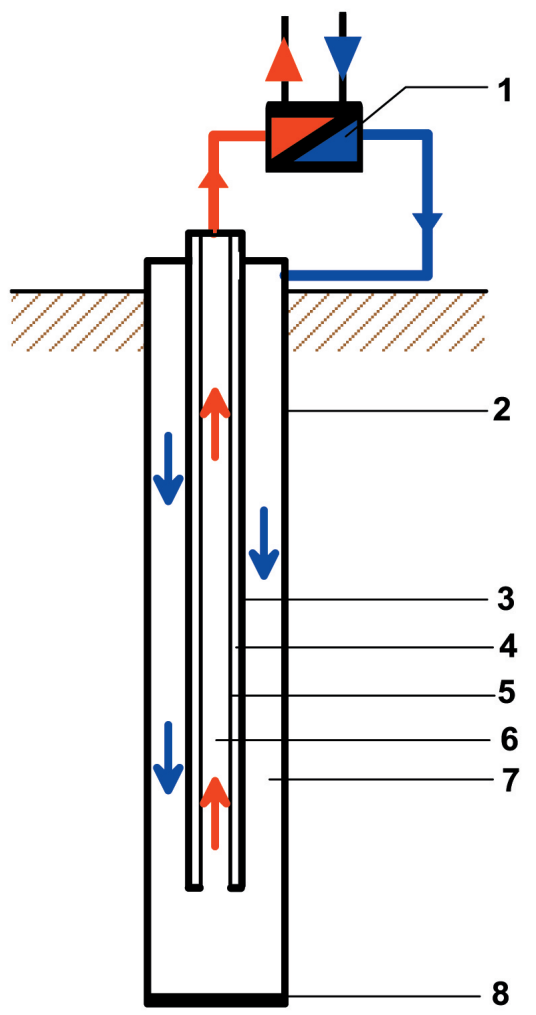

Fig. 3. BHE with double-layered insulated inner column, 1 - heat recipient (with/without heat pump), 2 - casing, 3 - outer pipe of double-layered coaxial column, 4 - annular between inner and outer double column, 5 - inner pipe of double coaxial column, 6 - heat carrier in inner column, 7 - hear carrier in annular between inner column and casing, 8 - cement plug and/or packer

Following DBHE construction can yield improved heat insulation, especially when gas (air or nitrogen) is used as a fluid inside the annular between double inner column. Additionally to much decreased thermal conductivity coefficient (from 0.025 to $0.032 \mathrm{~W} /(\mathrm{m} \cdot \mathrm{K})$ for nitrogen for temperatures between 0 and $\left.100^{\circ} \mathrm{C}\right)$, construction of double-layered pipe (two layers of steel and space in between) is also influencing effectiveness of the whole geothermal system.

Main disadvantages of described design are, as in previous case, necessity of using drilling rig with elevators and high hoisting capacity. Centralizers must assure that two 
pipes, creating double-layered pipe are stable inside the borehole. Running into the hole with inner column can be very complicated process, taking into consideration that space between two layers of steel pipe must be filled with insulating medium. Great care must be taken during sealing old production zone. Listed activities can carry high investment costs. Appling used elastic drill pipes as one of the double-layered pipes can greatly decrease the costs of an investment (especially with deeper boreholes).

Following construction design is also applied for column with VIT technology, described below, with an exception that between two pipes in inner column, during manufacturing, tight vacuum is created.

\subsection{Coaxial inner column with thermal insulation layer}

This construction design implies drill pipes, on which layer of insulating material, most commonly polyurethane foam or any material with good insulation properties, is applied. There are many technical possibilities of creating such insulating effect.

Application of polyurethane foam, used in manufacturing of district heating preinsulated pipes, involves delivering/shipping pipes to manufacturer. Process is conducted by applying an insulation layer of foam (or different insulating material) onto drill pipe. It is mandatory to create additional outer coat that will disable for heat carrier to saturate into polyurethane foam.

Making polyurethane insulation layer is achieved in two stages. In the first one, foam layer is applied onto drill pipe and in second one thread are insulated. Second stage must be carried during running in the hole and is achieved by using tightly secured plastic bands, after pipes are connected. Afterwards, small hole is drilled in the plastic band through which foam can be injected. This procedure will safely insulate space around pipe connection. Drilled holes need to be properly sealed after injection. Following insulation process around pipe connection can be achieved using thermophoresis process.

Other possibility is to apply prefabricated 'armour' from polyurethane foam onto not yet insulated pipe connections. Afterwards, protective band needs to be set up. Both cases described above imply application of protective (polymer) outer pipe.

Main limitation for following methods is depth of running in with the inner column inside the borehole. Such foam insulated pipes can withstand external pressure of 0.6 MPa. This phenomenon limits maximum depth of running such insulated pipes into the borehole, taking into consideration different specific weights of heat carrier and pressures losses, to around $500 \mathrm{~m}$. For polyurethane foam insulated pipes, different foam materials with higher density were investigated. This can enable to increase strength of insulated column and thus will enable to run in into greater depths. 
Main drawback of such column construction is increased cost caused by transport of drill pipes to an insulation manufacturer, time-consuming and complicated work concerning running into the borehole and probable damages during pulling out of the hole.

Such problems can be solved by using so called 'armour' made from other drill pipes with greater diameter. This can lead to extensive and complicated procedures during running in the hole. Polyurethane foam needs to be successively filled up during run-in with the insulated inner column. Parts of protective pipe have to be lowered simultaneously, when inner column maintains its steady position achieved by foam. Running with the inner column can be carried out without using a hook. This feature is very beneficial, as there is a possibility of connecting and making-up pipes more easily. Shear stress in foam, as well as in pipe-foam boundaries is lower than maximum permissible shear stress. Bottom of the inner column can be welded or sealed with packer.

This solution leads however to a construction design with double drill pipe, described previously, without a need to use foam.

Major advantage of described construction design is decreased total weight of the inner column, caused by higher buoyancy effect. As a result, drilling rig with lower hookload can be applied for run-in. Thermal conductivity coefficient of polyurethane foam used in this technical solution amounts to $0.024 \mathrm{~W} /(\mathrm{m} \cdot \mathrm{K})$ and is much lower than coefficients achieved in sections 2.2 and 2.3.

\subsection{Coaxial inner column made from polymer materials}

For boreholes drilled for extracting geothermal heat from underground reservoirs, elastic U-shaped inner column or coaxially placed two elastic pipes can be applied. Such low temperature heating systems with heat pumps include boreholes drilled up to 20-30 m of depth. This solution has many advantages, for instance, drilling rig with high hoisting capacity and elevators are not required. Elastic pipes can be easily connected during running into the borehole and can be also shipped and delivered in batches of desired length and diameter. Unfortunately, efficiency of elastic pipes is decreasing much with depth of the hole. Temperature difference of heat carrier flowing in and out of the BHE is increasing with the increment of depth. Elastic pipes have their limitations regarding maximum temperature outside and inside the pipe. This phenomenon is caused by restricted heat insulation. This construction design is fully sufficient for shallower wells. However, with increasing depth and determined flow rate of heat carrier, maximum temperature difference will be achieved inside the pipe and in annular, which will not change with further depth increment. Another restriction is mechanical strength, arising from external and internal pressure increase applied on pipes, as well as high temperatures. Thermal conductivity coefficient of such pipes can differ from lower to higher density materials. However average value for polyethylene tubes amounts to $0.42 \mathrm{~W} /(\mathrm{m} \cdot \mathrm{K})$. 


\subsection{Coaxial inner column made from polymer materials with higher wall thickness}

Following method gives similar results to the method before with an exception, that greater wall thickness can lower heat losses with temperature increase difference between internal and external of the pipe. Thermal conductivity coefficient of polymer materials presented in Figure 4 equals $0.22 \mathrm{~W} /(\mathrm{m} \cdot \mathrm{K})$ and is slightly lower than in section 2.4.

Polymer pipes might need additional load, when specific weight of pipe material will be less than specific weight of heat carrier. Additional load can be carried out together with centralisation of inner column.

In this design approach there is no need to use drilling rigs with high hoisting capacity and elevators to run in with the inner column. Similar to normal polymer pipe, mechanical and thermal stresses are bound to appear.

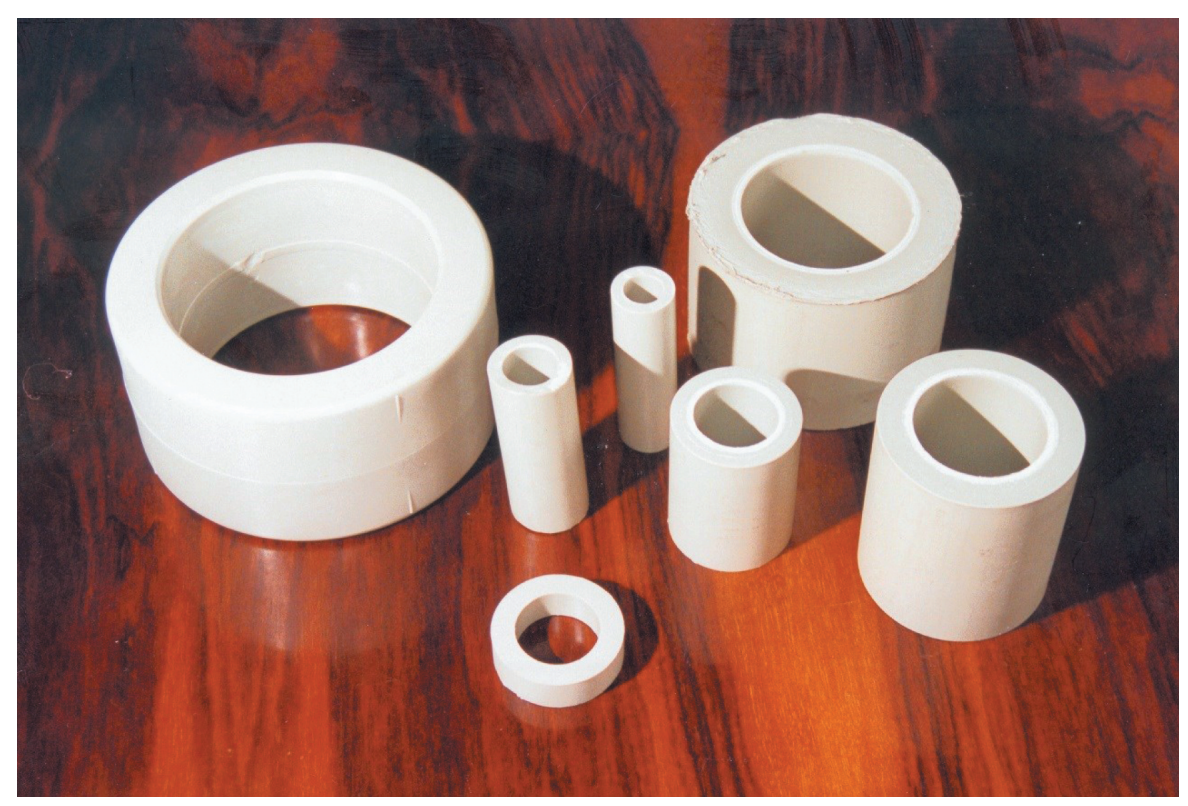

Fig. 4. Examples of polypropylene pipes with thermal conductivity coefficient of $0.22 \mathrm{~W} /(\mathrm{m} \cdot \mathrm{K})$

\subsection{Coaxial inner column made from double polymer pipe}

This particular approach combines construction design of double-layered, steel, coaxial inner column and polymer column. Annular can be filled with gas, foam or liquid. Major disadvantages are: high buoyancy effect, which must be solved by increasing 
the bottom weight of the column and depth restrictions on ground of allowable stresses caused by external and internal pressure.

Thermal conductivity coefficient for polyethylene materials equals $0.42 \mathrm{~W} /(\mathrm{m} \cdot \mathrm{K})$ and $0.22 \mathrm{~W} /(\mathrm{m} \cdot \mathrm{K})$ for polypropylene materials. Important parameter in this construction approach is discontinuity of pipe's material, i.e. space between two coaxial pipes, irregardless of fluid used to fill this space.

\subsection{Inner column selection}

Most important decisive factors of inner column selection are economic aspects and technical abilities (i.e. mechanical strength). It is crucial to analyse insulation of upper parts of the well, as temperature of circulating fluid in most cases is higher than temperature of upper rock formations [27]. Without proper insulation in layers close to the surface, heat carrier can cool rapidly.

Many mechanical stresses will occur in inner column during run-in and inside the borehole after setting tubing. These are compression, crushing and burst stresses. In static conditions, inner column is also influenced by external and internal hydrostatic pressures that can cause sudden collapse. Hardness is the most important mechanical parameter, if inner column is made from homogenous material.

There are many construction materials available on the market today, which mechanical resistance was not investigated in inner column's conditions. Such conditions can be called extreme on ground of high temperature and pressure. As a result of that, new research on such materials needs to be made. Some work on following aspects was investigated at Drilling and Geoengineering Department at Faculty of Drilling, Oil and Gas at AGH University of Science and Technology in Cracow, Poland.

Circulation of heat carrier will influence change of pressure distribution in the borehole. For wells with irregular axis or directional wells adopted for BHE, additional stresses in inner column are caused by inclination [28].

During design process, elongation of inner columns under its own weight (especially with steel drill pipes) or reduction in length (for polymer materials) has to be considered. Additionally, change of pipe's length caused by temperature has to be investigated, knowing that temperature profile inside the annulus varies from temperature profile inside inner column (Fig. 1).

Design methods for inner column in BHE's, considering mechanical stresses, are the same as during designing casing programs or Bottom Hole Assembly (BHA). Additional factor, which has to be included, is thermal expansion. This relates to temperature profiles inside the annulus and inner column during circulation that changes considerably with time. Methods of calculating mechanical stresses in pipes can be easily found in available literature $[29,30]$ and thus will be not mentioned in following article. 


\section{VACUUM INSULATED TUBING}

Vacuum tubing technology drastically decreases heat transfer between inner coaxial column and casing strings [16]. Such pipes are implemented to eliminate heat exchange caused by convection, radiation and conduction. VIT technology can lengthen lifespan of the DBHE systems, increase efficiency and decrease costs with very little impact on environment. Maximum bottom hole temperature for VIT application is $350^{\circ} \mathrm{C}$ and maximum depth is $3600 \mathrm{~m}$. Vacuum pipes can also be utilised in slim wells (holes with diameter 6" or less) [18]. Heat carrier in VIT loses around $12^{\circ} \mathrm{C}$ on $1542 \mathrm{~m}(5000 \mathrm{ft})$ length of pipe on average. In situation where conventional steel pipes are utilised, heat loss is around 8 times higher [17]. Vacuum pipes can demonstrate thermal conductivity coefficient varied from 0.06 to $0.0008 \mathrm{~W} /(\mathrm{m} \cdot \mathrm{K})$, whereas for conventional pipes it is around $40 \mathrm{~W} /(\mathrm{m} \cdot \mathrm{K})[17,18,21]$. As thermal conductivity for VIT can be only represented in particular range, manufacturers implemented insulating grades of VIT, which are represented by letter (e.g. B, C, E) [18, 20].

VIT constitutes of two coaxial steel pipes (mostly of different types of steel). Air between two steel pipes is evacuated using vacuum pump during manufacturing process. After achieving desired level of vacuum, pipes are sealed and welded together. This process creates very high thermal insulation and minimizes heat exchange between vacuum pipe and annulus [19]. There are three main areas of heat loss in VIT (Fig. 5):

- radiation through the vacuum area,

- radiation through the coupler,

- convection and conductivity along welds.

Thermal conductivity of VIT can be represented as a function of three different components and calculated from following equation [31]:

$$
k_{v i t}=k_{r a d}+k_{c o n d}+k_{c o n v}
$$

where:

$k_{\text {rad }}$ - radial term of thermal conduction of VIT, $\mathrm{W} /(\mathrm{m} \cdot \mathrm{K})$,

$k_{\text {cond }}$ - conductive term of thermal conduction of VIT, $\mathrm{W} /(\mathrm{m} \cdot \mathrm{K})$,

$k_{\text {conv }}-$ convective term of thermal conduction of VIT, $\mathrm{W} /(\mathrm{m} \cdot \mathrm{K})$.

Heat losses caused by convection and conduction are minor in comparison with these caused by radiation, especially radiation through couplers (from 50 to $90 \%$ of total heat loss). Considerably better thermal insulation exists through vacuum area, than through couplers [19, 32].

Figure 5 represents three main paths of heat loss. First one $\left(q_{1}\right)$ it is a radial heat loss along the annular $(10-50 \%$ of total heat loss in VIT), second one is radial heat 
loss through coupler $\left(q_{2}\right)$ and third path runs axially along inner column, then runs into the weld and from there migrates axially to the outer column $\left(q_{3}\right)$. Heat lost in third path can cover around $30-70 \%$ of total heat loss along vacuum pipes. Convectional heat losses are influenced heavily by buoyancy effect of heat carrier circulating in closed-loop system and temperature profile [31].

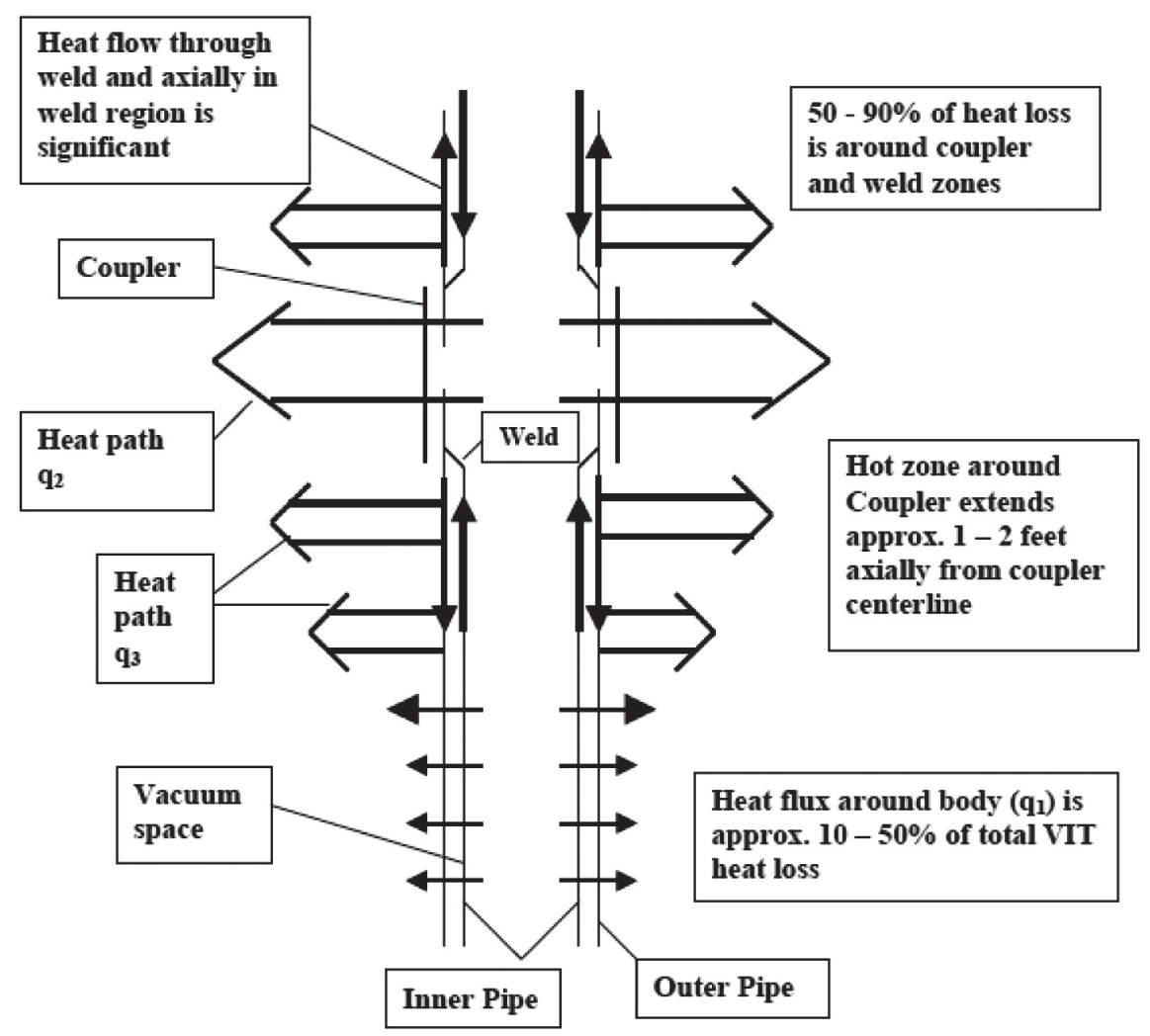

Fig. 5. Heat flow zones around Vacuum Insulated Tubing [31]

Major feature of VIT technology is non-mechanical chemical pump called getter (Fig. 6), which is found inside annular of vacuum column. This material consumes residual gasses, as well as gasses created during heat carrier circulation from steel pipes and additionally influences long-term viability of VIT. Getter converts gasses into solids and traps them within its matrix. This chemical pump mainly comprises of Vanadium, Zirconium and Iron, which are mixed together to create pills or granules. Getter materials are placed in close vicinity of inner column, where are easily activated by high temperature steam. The main purpose of getter is to maintain high-quality vacuum in VIT [19]. 


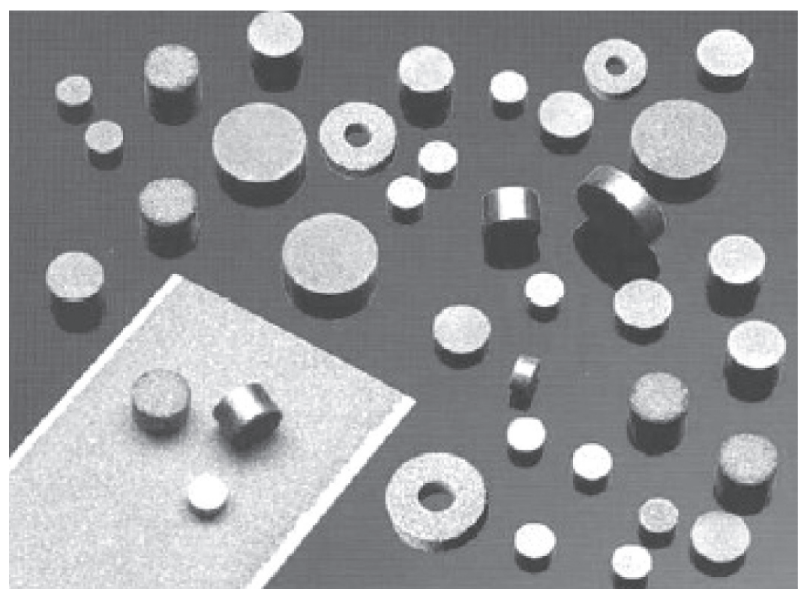

Fig. 6. Non-evaporative getter materials used in VIT technology [19]

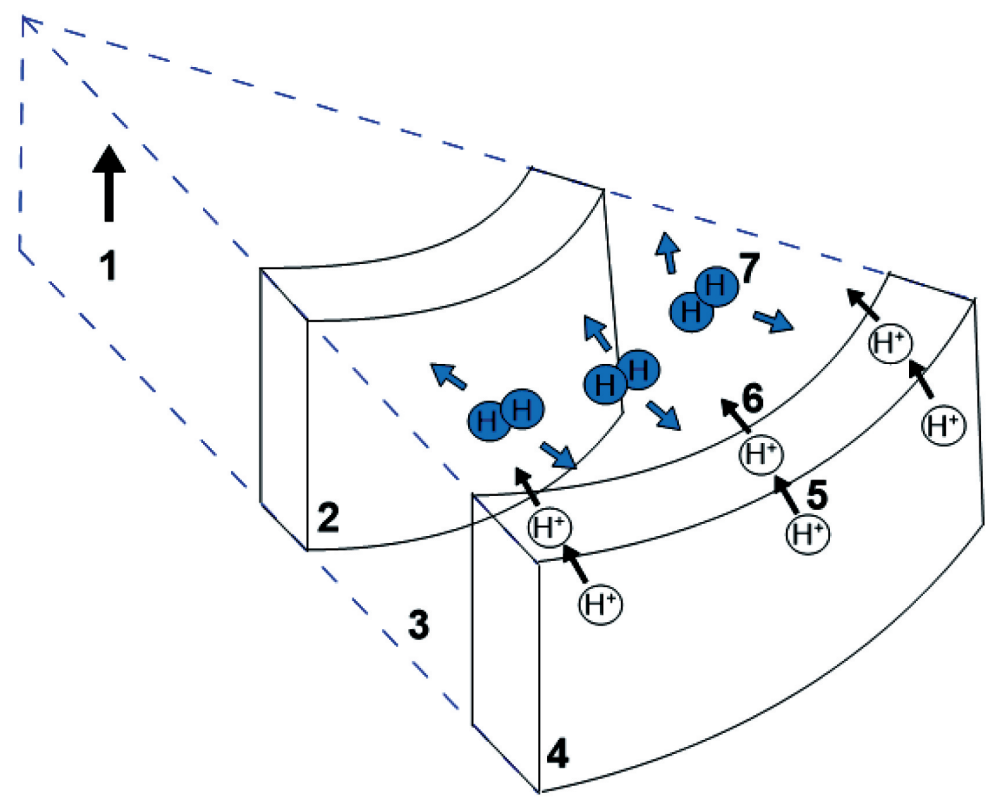

Fig. 7. Hydrogen permeation through Vacuum Insulated Tubing: 1 - direction of heat carrier, 2 - steel inner pipe of VIT with multiple anticorrosive and insulation layers, 3 - vacuum annular, 4 - steel outer pipe of VIT, $5-\mathrm{H}^{+}$absorption and absorption into steel pipe, 6 - diffusion of $\mathrm{H}^{+}$ in steel material, 7 - creation of $\mathrm{H}_{2}$ from combined $\mathrm{H}^{+}$atoms

The biggest problem during manufacturing and exploitation of VIT is hydrogen permeation (Fig. 7). This process impacts thermal insulation efficiency and increase 
heat transfer through inner column. Hydrogen can easily permeate most steel materials. Getter is a great absorbent of hydrogen permeating through vacuum annular, thus before VIT installation, amount of getter material, as well as potential hydrogen permeation need to be investigated by field testing or laboratory research [19].

Each vacuum pipe is connected using buttress threads (accordingly to API 5CT) together with internal coupling insulator, coupling and seal ring (Fig. 8). Inner VIT pipe is additionally coated with multiple insulating layers and aluminium foil. After evacuating air from VIT's annular and creating high-quality vacuum, each pipe is carefully tested. One of the most important tests is "k-value" test. There is no one value of thermal conductivity coefficient for vacuum pipes and thus values are presented in particular range [19]. Range of thermal conductivity coefficient can vary, depending on pipe's geometry, type of heat carrier circulating in heat exchanger, quality of medium inside annular of VIT, coupling thermal insulation and thermal conductivity of surrounding rock mass. L80 type of steel is most commonly used for outer pipe of VIT. As for inner pipe following steel types are used, 13CR85, 13CR95, 13CR110 [20]. Pipes with higher chrome content are applied for high-corrosive environments which can exist inside inner column.

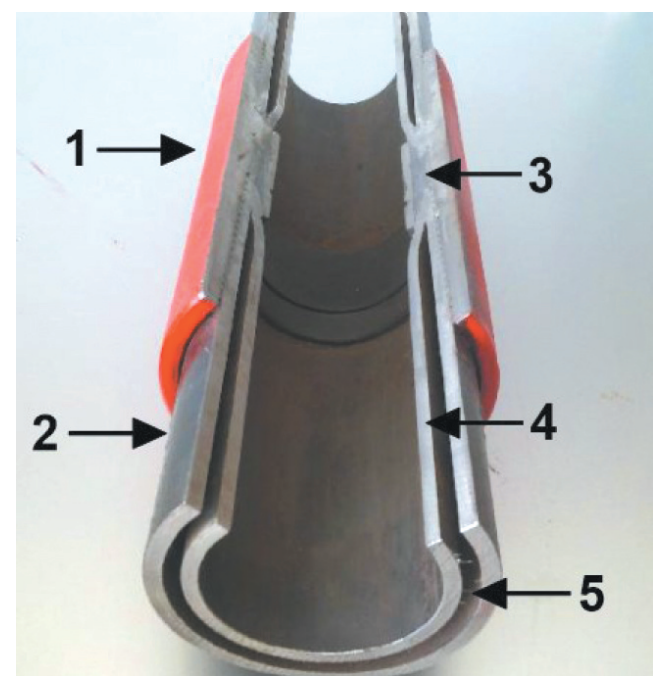

Fig. 8. Components of Vacuum Insulating Tubing:

1 - coupling, 2 - outer steel pipe (e.g. L80), 3 - internal coupling insulator and weld, 4 - inner steel pipe (e.g. 13CR85), 5 - vacuum with getter material [17]

\section{APPLICATIONS OF VIT TECHNOLOGY}

Further sections describe applications of VIT. Following technology can be applied not only in oil and gas industry, but also in transport of natural gas or in geothermal wells. 


\subsection{Annular Pressure Buildup mitigation}

Annular Pressure Buildup (APB) is the increase of pressure inside annular caused by thermal expansion of trapped wellbore fluids. Such problem exists in nearly every productive well, especially in deep water wells and is commonly ignored. Hydrocarbons production heats surrounding cement, as well as casing strings and annulus. Heat created during production of reservoir fluids influences pressure increase inside annulus, which might cause unfortunate effects such as well-pad destabilization, buckling or collapse of casing strings. VIT can easily mitigate APB and secure surrounding environment by decreasing heat transfer from inner column to annulus and further [17, 20, 32, 33].

\subsection{Gas hydrate formation prevention}

During well shut-in or sudden stops in production, hydrocarbons inside the well and around equipment are cooling very rapidly. This phenomenon leads to creating of hydrate plugs inside the well. VIT technology allows for longer heat retention and decreased heat transfer, thus temperatures inside the well will be higher than hydrate formation temperature. Such processes will significantly lower or even eliminate hydrates formation and decrease high repair costs [17, 20, 32].

\subsection{Paraffin and wax prevention}

During oil production there is a high risk of forming wax and/or paraffin deposits inside inner column, especially in areas with lower temperatures. Paraffin and wax complicate hydrocarbon production and can lead to full blockage of the well and finally production withhold. VIT technology helps to mitigate or even eliminate paraffin and wax formation by decreasing thermal conductivity and increasing heat retention. This also leads to decreased repair costs (heating up the well and/or pigging) [17, 20, 32].

\subsection{Heavy Oil Flow Enhancement}

Surrounding rock mass has a great impact on deep offshore wells producing heavy crude or extra heavy crude oil (API < 20). When temperature of oil, flowing up the well, is lower than temperature of surrounding rock mass, rapid increase of viscosity appears. This phenomenon leads to lower oil production and requires immediate repair work. Using VIT, constant viscosity of crude oil is maintained, without any additional source of heat. VIT application will significantly lower the costs of heating up the well and will also increase oil production [17, 20, 32].

\subsection{Enhanced Oil Recovery}

During enhancement oil recovery treatment, steam injected into the well can cause fracturing of surrounding cement and damaging casing strings, initiated by alternating 
low and high temperatures (thermal stresses). Created fractures can cause steam evacuation and simultaneously decrease efficiency of the enhancement recovery process. VIT technology secures the cement around the well and casing strings from possible damaging, provides better well integrity and increases the amount of steam injected into the well [17, 20, 32].

\subsection{Permafrost regions}

VIT technology is generally advised for oil and gas wells drilled in permafrost regions (e.g. Alaska, Canada). Oil production in such cold climate involves major heat transfer between the well and surrounding rock mass. This process can easily damage environment in the close vicinity of production wells. High heat transfer can drastically decrease well integrity, as the result of which unstable wells can collapse. VIT secures integrity of environment surrounding the well and eliminate risk of dissolving frozen rock formations [20, 32]

\subsection{Geothermal installations}

Vacuum pipes found its application also in geothermal industry [20, 21]. In wells drilled especially for DBHE or reconstructed for DBHE, inner column is the main feature that has a major impact on total efficiency of heat exchanger. Inner column needs to have lowest possible thermal conductivity for higher heat intake and as a result of that, higher profits. VIT technology becomes unbeatable among other construction designs, as it can work in HPHT conditions in deep wells ensuring minimum heat exchange [21].

Main drawback of such construction design in DBHE is high weight of inner column, which leads to increased costs of transport and running the column inside the borehole. Market price of following pipes is very high and there are also not many manufactures available [16].

VIT technology applied in geothermal wells extracting underground waters will drastically decrease heat losses during production (from underground water reservoir to the wellhead). For instance, in one of the polish geothermal plants (Geotermia Podhalańska S.A.) bottomhole temperature amounts to $90^{\circ} \mathrm{C}$ with wellhead temperature of $86^{\circ} \mathrm{C}$. Heat losses in such well with flow rate of $500 \mathrm{~m}^{3} / \mathrm{h}$ amount to around $2.2 \mathrm{MW}$ [34]. With VIT technology applied, heat losses can be considerably lowered or even eliminated.

\section{MANUFACTURERS OF VIT}

In Table 2 manufacturers (and/or providers) of vacuum tubing with country of origin and are presented. Different dimensions of VIT (diameter and weight) and steel types are also showed. Market price of 2300 meters of vacuum tubing amounts to approximately $1.2 \mathrm{mln}$ GBP (1.4 mln EUR). Cost of used VIT is much less and it amounts to around $0.8 \mathrm{mln}$ GBP (9.4 mln EUR) for the same length. Rented vacuum pipes can cost around $2 \mathrm{GBP} / \mathrm{ft}$ for 1 day $(7.5 \mathrm{EUR} / \mathrm{m})$ [17]. 


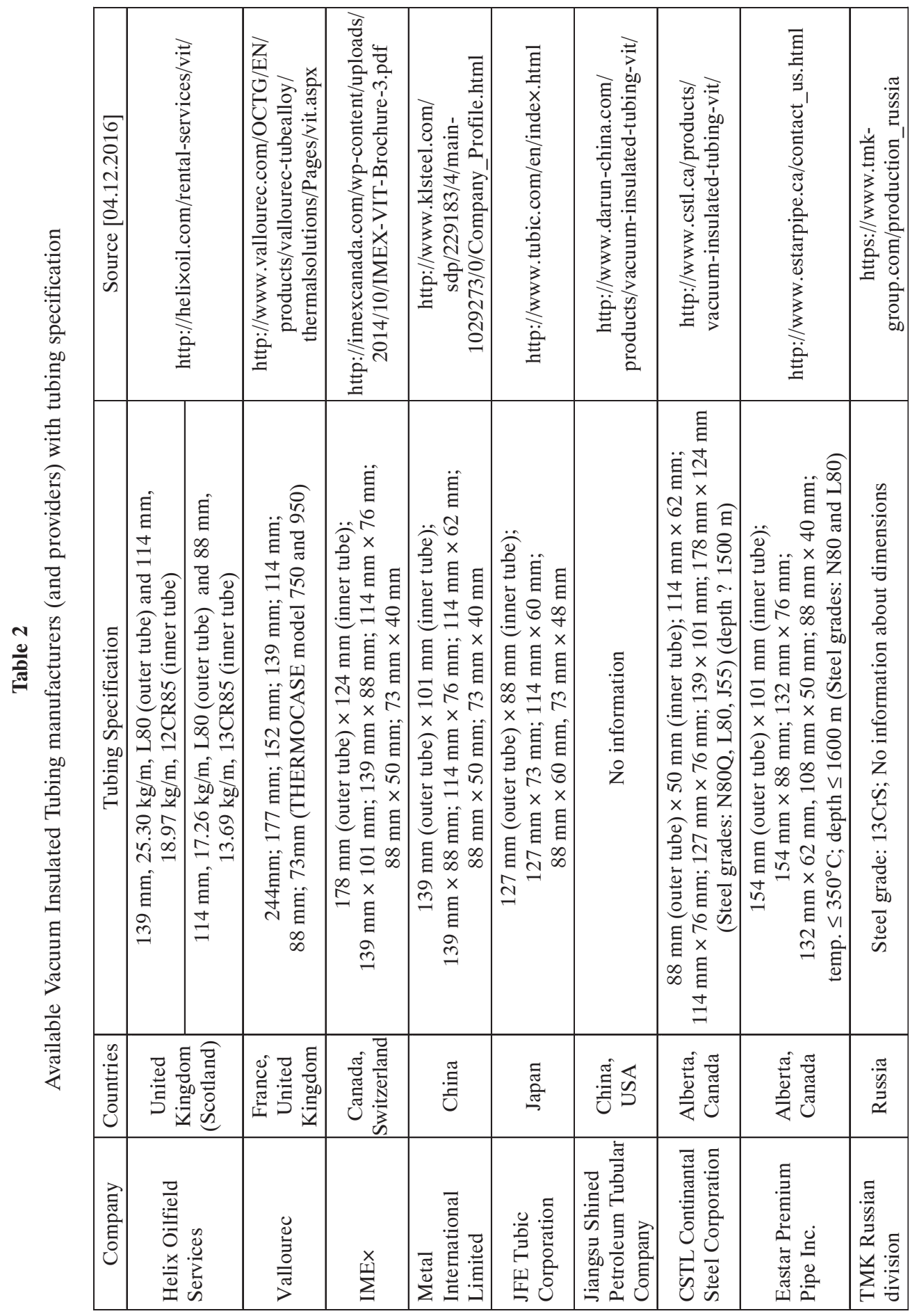




\section{SUMMARY}

1. BHE's and DBHE's are one of the best ways to utilise heat from reservoirs beneath the Earth's crust. These systems allow injecting fluids to the underground reservoir for further heat storage (heat resources regeneration in rock mass).

2. DBHE's can be utilised in old, abandoned or negative oil and gas wells. In this particular construction design it is possible to create much deeper installations, which can be used to exploit heat from underground reservoirs in direct manner (passive) or with heat pump (active).

3. Major feature of effective DBHE construction design is coaxial inner column, which enables circulation of the heat carrier in closed-loop or open system. Correct functioning of DBHE's involves installation of thermally insulated inner column that allows for heat carrier flow in opposite directions, upwards in inner column and downwards in annulus.

4. From available construction designs only VIT enables to create efficient DBHE system exceeding $2000 \mathrm{~m}$ depth. This, adapted from oil and gas industry, technology can significantly decrease thermal conductivity of inner column and lengthen lifespan of geothermal installation.

5. Vacuum pipes have two fundamental disadvantages that can eliminate their general use in DBHE's. These are, high investment cost and large inner column weight that involves expensive drilling rigs with high hoisting capacity and elevators for running in inside the borehole.

6. Currently, extensive research concerning finding new and inexpensive materials is being carried out. Following work constitutes of strength tests of different kinds of materials (mostly polymer) in extremely high temperature and pressure conditions. After finding the right construction material (inexpensive and light), DBHE will be able to economically compete with different ways of supplying recipients with heat.

\section{REFERENCES}

[1] Dincer I., Rosen M.A.: Thermal Energy Storage: Systems and Applications. 2nd ed. Wiley, London 2011.

[2] Jaszczur M., Polepszyc I., Sapinska-Sliwa A.: Numerical analysis of the boundary conditions model impact on the estimation of heat resources in the ground. Polish Journal of Environmental Studies 24/5A (2015), pp. 60-66.

[3] Jaszczur M., Sliwa T.: A Long-term Analysis of a borehole Heat Exchanger System, Proceedings ECCOMAS Special Interest Conference. Numerical Heat Transfer 2012, 4-6.10.2012 Gliwice-Wrocław, Poland. 
[4] Kurevija T., Vulin D., Krapec V.: Effect of borehole array geometry and thermal interferences on geothermal heat pump system. Energy Conversion and Management, 60, 2012, pp. 134-142,

[5] Li M., Li P., Chan V., Lai ACK.: Full-scale temperature response function (G-function) for heat transfer by borehole ground heat exchangers (GHEs) from sub-hour to decades. Applied Energy, 136, 2014, pp. 197-205.

[6] Sliwa T., Rosen M.A.: Natural and Artificial Methods for Regeneration of Heat Resources for Borehole Heat Exchangers to Enhance the Sustainability of Underground Thermal Storages: A Review. Sustainability, 7/10, 2015, pp. 13104-13125,

[7] Tomaszewska B., Pająk L.: Geothermal Water Resources Management-Economic Aspects of their Treatment. Mineral Resources Management [Gospodarka Surowcami Mineralnymi], 28/4, 2012, pp. 59-70, https:/www.min-pan.krakow.pl/ Wydawnictwa/GSM284/tomaszewska-pajak.pdf [24.08.2016].

[8] Sliwa T, Kotyza J.: Application of existing wells as ground heat source for heat pumps in Poland. Applied Energy, 74, 2003, pp. 3-8.

[9] Knez D.: Stress State Analysis in Aspect of Wellbore Drilling Direction. Arch. Min. Sci., 59/1, 2014, pp. 7169-764, http://mining.archives.pl/index.php/index.php?option $=$ com_remository\&Itemid $=0 \&$ func $=$ fileinfo\&id $=705 \&$ lang $=p l \quad[24.08 .2016]$.

[10] Zarrella A., Capozza A., De Carli M.: Analysis of short helical and double U-tube borehole heat exchangers: A simulation-based comparison. Applied Energy,112, 2013, pp. 358-370.

[11] Zarrella A., De Carli M.: Heat transfer analysis of short helical borehole heat exchangers. Applied Energy, 102, 2013, pp. 1477-1491.

[12] Li M., Lai ACK.: Heat-source solutions to heat conduction in anisotropic media with application to pile and borehole ground heat exchangers. Applied Energy, 96, 2012, pp. 451-458.

[13] Sliwa T.: System grzewczo-chtodniczy na bazie wymienników otworowych $z$ bezpośrednim parowaniem czynnika roboczego w centrum Pałecznicy [Heating and refrigeration system based on borehole heat exchangers with direct evaporation in the center of Pałecznica]. Proceedings of Conference „Efektywność energetyczna w gminach na przykładzie Pałecznicy" [Energy efficiency in communes on example of the village Pałecznica], Pałecznica 16 października 2014 r., red. Tomasz Śliwa, pp. 1-9.

[14] Sapinska-Sliwa A., Rosen A.M., Gonet A., Sliwa T.: Deep Borehole Heat Exchangers - A Conceptual Review. Proceedings World Geothermal Congress 2015, Melbourne, Australia 19-25 April 2015.

[15] Sliwa T., Gonet A., Sapinska-Sliwa A., Knez D., Jezuit Z.: Applicability of Borehole R-1 as BHE for Heating of a Gas Well. Proceedings World Geothermal Congress 2015, Melbourne, Australia 19-25 April 2015. 
[16] Sliwa T., Nowosiad T., Vytyaz O., Sapinska-Sliwa A.: Study On The Efficiency Of Deep Borehole Heat Exchangers. SOCAR Proceedings, Reservoir and Petroleum Engineering, No. 2, 2016, pp. 029-042.

[17] HELIX Oilfield Services, Company Brochure.

[18] IMEX Canada Inc., Company Brochure.

[19] Lombard S.M.: What Every Engineer Should Know About Vacuum Insulated Tubing. SPE, Oil Tech Services Inc., SPE 153837, 2012.

[20] Vallourec Tube-Alloy, Company Brochure.

[21] Morita K.: One Possible Way to Utilize Abandoned Deep Wells - the Application of the DCHE. Proceedings Geothermal Energy in Underground Mines, Ustron, Poland, 2001.

[22] Rubik M.: Pompy ciepła Poradnik. Branżowy Ośrodek Informacji Naukowej, Technicznej i Ekonomicznej „Instal”, Warszawa 1996.

[23] Sliwa T., Gonet A.: Theoretical model of borehole heat exchanger. Journal of Energy Resources Technology, vol. 127, No. 2, 2005, pp. 142-148.

[24] Kohl T., Brenni R., Eugster W.: System performance of a deep borehole heat exchanger. Geothermics, 31, 2002, pp. 687-708.

[25] Sliwa T., Kotyza J.: Dobór optymalnego otworowego wymiennika ciepta w otworze Jachówka $2 \mathrm{~K}$ do glębokości $2870 \mathrm{~m}$ [Selection of optimal construction of borehole heat exchangers based on Jachówka 2K well to a depth $2870 \mathrm{~m}]$. in: Sokołowski J. (ed)., Metodyka i technologia uzyskiwania użytecznej energii geotermicznej z pojedynczego otworu wiertniczego [Methodology and technology of obtaining usable energy from a single geothermal borehole]. PGA, Polgeotermia, PAN, Kraków 2000, pp. 251-284.

[26] Busser G.C., Sliwa T.: The use of GRE (fiberglass) tubulars in oil - gas - geothermal industry. Proceedings: 15th International Scientific and Technical Conference "New Methods and Technologies in Petroleum Geology, Drilling and Reservoir Engineering", WWNiG AGH, Kraków2004, pp. 21-28.

[27] Dijkshoorn L., Speer S., Pechnig R.: Measurements and design calculations for a deep coaxial borehole heat exchanger in Aachen, Germany. International Journal of Geophysics, Article ID 916541, 2013, p. 14.

[28] Sapinska-Sliwa A., Rosen M.A., Gonet A., Sliwa T.: Deep borehole heat exchangers - a conceptual and comparative review. International Journal of Air-Conditioning and Refrigerationvol, 24, Iss. 1, 2016, pp. 1-15, art. No. 1630001.

[29] Gonet A., Sliwa T., Stryczek S., Sapińska-Sliwa A., Jaszczur M., Pająk L., Złotkowski A.: Metodyka identyfikacji potencjatu cieplnego górotworu wraz z technologia wykonywania $i$ eksploatacji otworowych wymienników ciepła. Wydawnictwa AGH, Kraków 2011.

[30] Szostak L.: Wiertnictwo. Wydawnictwa Geologiczne, Warszawa 1989. 
[31] Azzola J.H., Richey J. F.: The Heat Transfer Characteristics of Vacuum Insulated Tubing. SPE 90151, Tube-Alloy Products, 2004.

[32] Kang Y., Saumel R., Gonzales A., Liu Z., Halliburton: Heat Transfer Modelling of Wellbore with Vacuum Insulated Tubing (VIT). SPE 178449 MS, 2015.

[33] Moe B., Erpelding P.: Annular pressure buildup: What is and what to do about it. Oil Technology Services Inc., Houston 2005.

[34] http://geotermia.pl/energia-geotermalna-na-podhalu/ [09.04.2017].

[35] Gonet A., Stryczek S., Rzyczniak M.: Projektowanie otworów wiertniczych. Wydawnictwa AGH, Kraków 1996.

[36] Kizilkan O., Dincer I.: Borehole thermal energy storage system for heating applications: Thermodynamic performance assessment. Energy Conversion and Management, 90, 2015, pp. 53-61.

[37] Sliwa T., Gonet A., Munia J., Kozioł W., Pająk L.: Nowy kierunek wykorzystania odwiertów przeznaczonych do likwidacji [New direction of abandon wells reuse]. Proceedings: Problemy rekonstrukcji i likwidacji odwiertów ropnych i gazowych w Karpatach i na Przedgórzu: I konferencja naukowo-techniczna: Rudawka Rymanowska-Bóbrka, 11-13 października 2000 r. PGNiG S.A. O/ZRG Krosno; SITPNiG O/Krosno, 2000, pp. 7-1-7-14. 